\title{
Personal Pronouns as the Constructor of Speaker Identity: Analysis in Javanese Text
}

\author{
Yudha Adi Candra ${ }^{1}$, Atin Fitriana ${ }^{2}$, and Dwi Puspitorini ${ }^{3}$ \\ \{yudha.adi@ui.ac.id ${ }^{1}$, atin.fitriana81@ui.ac.id², dwi.puspitorini@ui.ac.id ${ }^{3}$ \} \\ 1,2,3 Javanese Literature Study Program, Faculty of Humanities, Universitas Indonesia, \\ Indonesia
}

\begin{abstract}
One of language that has honorific markers in its usage of personal pronouns is Javanese. Javanese has several speech levels. This distinctive distribution of speech levels exists only in Modern Javanese. In Old Javanese, that distribution is not found. This article discusses the use of personal pronouns of Javanese in a speech act situation. The data used in this research are two texts that were written on different times. Ādiparwa text represents the use of personal pronouns of Old Javanese, and Pedhalangan text represents the use of personal pronouns of Modern Javanese. This research uses both data to see how the identity of speakers is formed through the use of personal pronouns in Old Javanese text and Modern Javanese text. The results indicates that the identity of speakers in Modern Javanese texts is influenced by the use of personal pronouns tied by the use of speech level, whereas in Old Javanese text, the identity of the speaker is influenced by the use of personal pronouns and the utterance context. In Old Javanese texts, speakers can present different identities in one utterance, whereas in the Modern Javanese, speakers can only indicate one identity in one utterance.
\end{abstract}

Keywords: personal pronouns, Javanese, identity, speaker, speech act

\section{INTRODUCTION}

Javanese is one of language that has many texts and Javanese manuscripts. The text and manuscripts are written in modern Javanese and Old Javanese. There are many things that can be extracted from Javanese texts or manuscript, one of them is its linguistics aspect. These linguistic aspects can be related to Javanese culture or Javanese way of thinking. Interesting linguistics aspect to be explored is the use of personal pronouns. The use of personal pronouns is also related to the use of honorific marker [1]. The honorific marker is closely related to languages variety. One of language that has honorific markers in its usage of personal pronouns is Javanese.

Javanese has several speech levels. Javanese is divided by the speech level of ngoko, madya, and krama [2]. The variety of Javanese speech level is used based on the situation and context of specific speech acts. Ngoko is the basic level used in more intimate situation, equal, or used by speakers who have a higher position. Meanwhile, krama is a more polite level used in nonintimate situations by low-ranking speakers to high-ranking people. 
This distinctive distribution of speech levels exists only in Modern Javanese. In Old Javanese, that distribution is not found. However, based on the usage, personal pronouns in Old Javanese are more than in Modern Javanese. In Old Javanese, the closeness of the relation between speakers and speech partner cannot be observed based on the level of speech. The relation between speaker and speech partner must be seen through the use of personal pronouns and the context around utterance. There have been several studies that discussed about personal pronouns in Modern Javanese [3] [2]. Meanwhile, research on personal pronouns of Old Javanese has been done [4], [5], [6], [7] Although there has been considerable research on personal pronouns, the research on the comparison of personal pronouns usage in Modern Javanese and Old Javanese language, especially in Pragmatic field, has not been conducted.

Based on the above explanation, this research aims to find out the use of personal pronouns of Old Javanese and Modern Javanese in Javanese text and to illustrate the construction of speaker identity. In this matter, the speaker identity is important to know because the utterance that contains the use of personal pronouns is in the speaker's utterance. In addition, to know the relation that exists between speech participants, the speaker identity holds important portion to be observed.

The study of pronouns is not only discussed by the field of linguistic, but also discussed by other fields. The fields of philosophy, sociology, anthropology, and psychology also examine pronouns [1]. The things discussed in the study of pronouns are: what is pronoun; the relations between individual identity and pronouns; and how to identify someone over the others. Pronouns marker is not only related to the first, second, and third person, but also relates to information about the social status of the speaker and the relations between speaker and speech partner [1].

The article entitled Persons, Identities, and Social Interaction explains the concept of identity in relation to pronouns and social interaction [8]. According to them, the concept of identity is formed because of the relation between pronouns and social structure. Pronoun identity is defined through identification process, namely the process of naming and labeling on someone who brings social status into an interaction. Thus, it can be seen that a person's identity is formed over a process of labeling of individual (social status) in an interaction. Therefore, social status cannot be separated away from someone's identity.

Research on the use of personal pronouns in a communication context, has been conducted in many languages, such as Slovak language and Japanese. [9] Conducted a research on the use of personal pronouns $j a[\mathrm{I}]$ and on [he] in a communication context. The focus of the research was personal pronouns subsystem in a spontaneous communication. Then, the use of personal pronouns is associated with the explicit motivation of the subject of pronouns. Meanwhile, research on pronouns of Japanese was conducted by [10]. In his research, [10] examined the use of first and second person pronouns in a speech act. The purpose of the research was to contrast the use of the first and second person pronouns in a discourse by using speech act theory (Austin). The results showed that the discursive situation able to describe the function of personal pronoun. In the case of a discursive role, the speaker is not only able to express himself, but also as a target of certain illocutionary acts.

Meanwhile, in relation to personal pronouns of Javanese, the research on personal pronouns of Old Javanese have been conducted in the article Person in Kawi: Exploration of an Elementary Semantic Dimension [6]. In their research, they both analyze person deixis based on the smallest aspect; the sounds and phonemes. In person deixis, personal pronouns was divided into two based on distance; close and far [6]. The distance is a relation based on interpersonal and social relation. The distribution of personal pronouns [6], namely: 
Tabel 1. Pronomina persona

\begin{tabular}{|l|l|l|}
\hline & Close & Far \\
\hline Speaker & $A k u$ & Kami \\
\hline Listener & $K a(N) u$ & Kita \\
\hline Third person & $I a$ & Sira \\
\hline
\end{tabular}

Based on the above table, it is seen that personal pronouns is divided based on the relationship between speech participants. First person pronouns aku and kami 'I' are used differently by distance (close and far). Second person pronoun are in the form of kamu or kanyu and kita are 'you', while third person pronoun can be both ia and sira 'him'. Both second and third person pronouns are also distinguished by the distance (close and far). In contrast to Becker and Oka's opinion, there is no difference between the use of first person pronouns $a k u$ and kami [7]. These two pronouns may be used in the same usage and in the same sense. Indirectly, the two first person pronouns can be exchanged in the same situation [7].

Based on the two premises above, it appears that research or study of personal pronouns is not fully completed. There is dissimilarity between one premise and another. Looking at the use of personal pronouns in Modern Javanese today, each personal pronoun serves a specific situation [6]. Therefore, that opinion is used as a basis in observing the use of personal pronouns of Old Javanese.

Meanwhile, research on personal pronouns of Modern Javanese in pragmatic field has been done [2]. Related to the usage in a social situation, person deixis in Javanese is closely related to social deixis. Each form of personal pronouns has different usage criteria with regard to the social aspect of the speaker [2]. The form of personal pronouns used by the speaker relates to social status or social position of the speaker and their relation to participants in speech event.

Related to the use of personal pronouns in a speech act situation, speakers have a particular intention in using personal pronouns in an utterance. Speakers can convey specific intentions either directly or indirectly. The speaker's intention conveyed impliedly is called implicates. Through implicatures, the speaker can convey certain intentions without necessarily conveying them directly. Implicatures are part of speaker's meaning in an utterance without having to be part of what is said [11]. In a communication situation, the desired meaning (unsaid) is richer than what is said directly [11].

\section{METHOD}

In this research, there are 2 data source used; the data source of Old Javanese and the data source of Modern Javanese. The data source that represents the usage of Old Javanese is $\bar{A}$ diparwa text.Ádiparwa text used in this research is a text edition of [12]. Meanwhile, the data source used to represent the use of Modern Javanese is Pedhalangan text entitled Pedhalangan Djangkep Sedalu Muput lampahan Kartopiyoga Tjidra [13].

The method used in this research is qualitative method. Data of personal pronouns are collected from 2 data sources. The collection of personal pronouns data is restricted to the use of first person pronouns. In addition, the selection of first person pronouns in Adiparwa text is also limited by the highest frequency of occurrences within the text. After data has been collected, the data are classified by interpersonal relations, such as relations that show symmetric and asymmetric relations. Then, personal pronouns are analyzed based on its use in an utterance, context of utterance, and meaning of utterance. Through this method, the identity of the speaker formed through the use of personal pronouns in an utterance can be observed. 


\section{RESULT AND DISCUSSION}

Based on the analysis performed, this study shows that the identity of speakers represented through the use of personal pronouns in both texts is similar. "One of the ways identity is marked linguistically is through the differential use of pronouns" [14]. However, in the text of Pedhalangan, the speaker's identity is not only observed based on the use of personal pronouns only, but also influenced by the level of speech. The use of personal pronouns in an utterance is adjusted or strongly influenced by the level of speech. The leve of speech in a speech event is adjusted or strongly influenced by context. The speech level is not only related to the use of personal pronouns, but also affects the words choice used in a speech event. Meanwhile, in Old Javanese (in Adiparwa text), the use of personal pronouns is not determined by the level of speech. Identity differences can be identified based on the use of personal pronouns and the context of utterance.

In Adiparwa and Pedalangan texts, there are several usages of first and second person pronouns that indicate the identity of speakers and interpersonal relation. That is appropriate with the statement that the use of first and second person pronouns as a marker of identity and qualifier of relationships [15]. The relations may be equal and unequal relations. Although interpersonal relation can be easily classified, the context and meaning of utterance indicates different identity of each character.

\subsection{The Use of First Person Pronouns in Adiparwa Text}

In the Adiparwa text, first person pronouns with a high frequency of occurrences are $a k u$, kami, and nghulun 'I'. The three of first pronouns are sometimes used simultaneously in one utterance. Although these three pronouns are used simultaneously, their usage shows different functions. Look at Sentence (1) below.

(1) "Sugyan tan wruha ri kami, aku si Kindamana brāhmaṇa nghulun, tamolah agawe tapa makāhāra sarwalatā." (116.19-20)

'You don't know me! I am Kindamana, I am a Brahmin who routinely performs meditation by making woodbine plants as food'

Sentence (1) is a sentence uttered by rsiKindamana to maharajaPandu. The relation between the two is an unequal relation. In that sentence, rsi Kindamana uses three distinct first pronouns simultaneously in one utterance. Through the use of first pronouns, Rsi Kindamana or speaker is showing his identity indirectly toward the speech partner. The identity is not only related to social status, but also relates to how speaker place himself before hisspeech partners. Socially, rsi Kindama is a Brahmin, while Pandu is a great king. However, in an utterance with the word kami'I', rsi Kindamana present himself equal to his speech partner, maharaja Pandu. The purpose of the utterance is to tell the speech partners, that the speaker is a Rsiwho is also known by many people, alike his speech partner. Therefore, rsi Kindamana presents himself equally to Pandu in terms of fame.

In the same sentence (Sentence 1), rsi Kindamana indirectly presents himself higher than maharaja Pandu. In that utterance, the speaker explains that he is rsi Kindamana's. Related to the previous utterance, he wants to show that rsi Kindamana is a famous person. Through the utterance, the speaker introduces himself by mentioning his name. Everyone knows who rsi Kindamana is, so rsi Kindamana think that maharaja Pandu should have known his name. In that utterance, rsi Kindamana places himself higher to show different identity beyond his name; his fame in the community. 
In the following utterance, rsi Kindamana uses personal pronouns nghulun 'I' to identify himself as a Brahmin. Personal pronouns nghulun 'I' are commonly used by speakers whose position is lower than the speech partner. The position is not only by social status, but also influenced by many other factors. Through the use of personal pronouns nghulun, rsi Kindamana places himsel flower to maharaja Pandu. It is intended to show his identity as Brahmin. The characteristics of a Brahmin should be reflected from what he says. Therefore, the social status (Brahmin) in the utterance is juxtaposed with personal pronouns nghulun. In addition to show his identity as a Brahmin, through the use of personal pronouns nghulun, rsi Kindamana also shows another identity, which is how life is lived by Kindamana as a Brahman. Rsi Kindamana wants to show that the attitude or way of life that he is doing is good and not wrong.

Based on the use of the three of first three pronouns, it appears that speakers can present different identities and meanings in each utterance. "Each use of a pronoun constructs some part of the identity of the speaker in real time" [14]. These differences are not only influenced by the use of personal pronouns, but also influenced by the context of utterance. In Adiparwa text, speakers are enabled to use several different forms of personal pronouns to refer to themselves. It depends on the speaker's purpose in conveying the meaning of the utterance and in presenting the speaker's identity to the speech partner.

\subsection{The Use of First Person Pronouns in Pedhalangan Djangkep Sedalu Muput lampahan Kartopiyoga Tjidra Text}

In contrast to the use of first person pronouns of Old Javanese, the use of different personal pronouns of modern Javanese cannot be used simultaneously in one utterance. It is influenced by the level of speech in modern Javanese. The use of the first person pronouns in the text are $a k u$, kula, kawula, and ingsun. The following is the examples of the use of those personal pronouns.

(2) “Kakang, ana wong mbarang ngamuk kakang, aku tulungana" (76:1)

'Brother, someone is raging, please help me.'

Sentence (2) is uttered by Bratajaya to Jaladara. Bratajaya is the younger brother of Jaladara. By age, Bratajaya is younger than Jaladara. In that utterance, Bratajaya uses the first person pronoun $a k u$ 'I' to refer to himself. Personal pronouns $a k u$ in the utterance is used by Bratajaya to appeal for assistance to Jaladara. The assistance requested was to calm Arjuna who was angry. Arjuna's anger was caused by the offering (food) given by Bratajaya which was considered as an isult to Arjuna because it was mixed up like animal food.

Based on the level of speech, Bratajaya uses ngoko or usually used in situations of equal relation and informal situation. The use of personal pronouns $a k u$ and the level of speech used indicates that the speakers are equal and close to the speech partner. Although the purpose of the utterance is to ask for help to the speech partner, but in that utterance, the speaker does not put himself under his speech partner. This can be seen in the selection of ngoko words used in the speech event, such as the verb tulungana 'please help'.

Through the use of personal pronouns and speech levels, it appears that speaker want to present himself that he has a personal closeness with the speech partner and without distance in between.

(3) "nuwun inggih kangmas Burisrawa, kula aturi nyekecakaken lenggah" (32:27)

'Dear Brother Burisrawa, I invite you to sit down'

Sentence (3) is uttered by Rukmarata to Burisrawa. Rukmarata is the younger brother of Burisrawa. Based on the position, Buriswara has higher position compare to Rukmarata. In that 
utterance, Rukmarata uses first person pronoun kula 'I'. In addition, Rukmarata as a speaker also uses krama; level of speech that commonly used in unequal relation or formal situation, althogh both have personal proximity. The use of first person pronouns kula and krama level by the speaker indicates that Rukmarata places himself lower than his speech partner. Based on the context of utterance, Rukmarata would like to invite his speech partner to discuss important matter.

(4) “Sanget pamundi kawula pangestunipun kanjeng sinuwun”(13:37)

'I wish to receive your prayers and blessings'

Sentence (4) is uttered by Tuhayata to King Salya. Patih Tuhayata is the prime minister of King Salya. In that utterance, Tuhayata uses the first person pronoun kawula 'I'. Personal pronouns kawula means a person who devoted his life to someone. Through the use of personal pronouns kawula, it appears that speaker is very respectful to the speech partner. Based on the context of utterance, Patih Tuhayata faces Prabu Salya in formal situation to report the current condition of the kingdom. This is because the speaker (Patih) is a servant of King Salya. Tuhayata shows that based on his social status he is lower than his speech partner. Therefore, Tuhayata uses personal pronouns kawula to refer to himself. In addition to the use of personal pronouns kawula, the speaker also uses the level of speech of krama in the utterance.

(5) “Iya patih, ingsun tampa pangabektinira pangestuku bae genti tampanana" (13:35)

'Yes Prime Minister, I accept your honor, instead, please accept my prayers and blessings.'

Sentence (5) is uttered by King Salya to Patih Tuhayata after Patih Tuhayata finished giving honor to King Salya in Kingdom meeting. The use of personal pronouns in Sentences (4) and Sentence (5) is different. In sentence (5), the personal pronoun used is ingsun 'I'. The use of pronoun ingsun is the same as the use of personal pronoun $a k u$. However, the use of pronouns ingsun shows a sense of reluctant as a form of respect. Through the use of personal pronouns, the speaker wants to show that although his position is higher than his speech partner, he still respects him. The respect is addressed because of the position owned by his speech partner, namely Patih (prime minister). The position of Patih is one of high and important positions in the royal system. Based on the level of speech, King Salya uses Ngoko speech level. It also supports that personal pronoun ingsun is used by someone who has a higher position toward the speech partner.

Based on the examples (2) until (5), it appears that the use of personal pronouns is also determined by the use of speech levels in an utterance, such as ngoko and krama. This is in contrast to the use of personal pronouns in example (1). In example (1), the use of personal pronouns does not depend on the level of speech.

\section{CONCLUSION}

This research is a preliminary research, so the result obtained is an early description about the use of personal pronouns in Javanese. This is because the data of pronouns discussed in this research is still limited. Nevertheless, the results of this research can contribute to the research on Javanese (Old Javanese and Modern Javanese). In order to reveal the function of personal pronouns as one of identity constructor, it requires a lot of data of personal pronouns usage. However, based on the above discussion, it can be observed that the use of personal pronouns of Old Javanese and Modern Javanese as identity constructor are represented in different ways. In Old Javanese, the speaker identity cannot only be seen from the use of personal pronouns, 
but also must consider the aim of the speech conveyed by the speaker. Meanwhile in Modern Javanese, the use of personal pronouns as a form of speaker identity is observed from the languages variety used when the speech event takes place. However, languages variety or speech levels sometimes do not necessarily show the speaker identity clearly. Some of them require speech context in order to be able to show the speaker identity in a speech event.

\section{ACKNOWLEDGEMENT}

"This work is supported by Hibah PITTA 2018, funded by DRPM Universitas Indonesia, No.1993/UN2.R3.1/HKP.05.00/2018"

\section{REFERENCES}

[1] A. Siewierska, Person. Cambridge: Cambridge University Press, 2004.

[2] F. X. Rahyono, Ekspresi Deiktis Bahasa Jawa. Depok: FIB UI, 2002.

[3] E. M. Uhlenbeck, Studies in Javanese Morphology. The Hague: Martinus Nijhoff, 1978.

[4] E. M. Uhlenbeck, "Personal pronouns and pronominal suffixes in old Javanese," Lingua, vol. 21, pp. 466-482, 1968.

[5] Teselkin, Old Javanese (Kawi). New York: Cornell University, 1972.

[6] A. L. Becker and I. G. N. Oka, "Person in Kawi : Exploration of an Elementary Semantic Dimension Author ( s ): A . L . Becker and I . Gusti Ngurah Oka Source : Oceanic Linguistics , Vol . 13, No . 1/2, Papers of the First International Conference on Comparative Austronesian Linguist," vol. 13, no. 1, pp. 229-255, 1974.

[7] P. J. Zoetmulder and I. R. Poedjawijatna, Bahasa Parwa. Yogyakarta: Gadjah Mada University Press, 1992.

[8] L. Freese and P. J. Burke, "Persons, identities, and social interaction," Adv. Gr. Process., vol. 11, pp. 1-24, 1994.

[9] M. Bodnárová, "Personal Pronouns ja [I] and on [he] in the Communication Context," J. Linguist. Cas., vol. 67, no. 2, pp. 107-124, 2016.

[10] E. Oishi, "Discursive Function of Japanese Personal Pronouns," Russ. J. Linguist., vol. 21, pp. 305-319, 2017.

[11] L. R. Horn, "Implicature," in The Handbook of Pragmatics, L. R. Horn and G. Ward, Eds. UK: Blackwell Publishing, 2006.

[12] H. H. Juynboll, Ādiparwa. Oud-Javaansch Prozageschrift. 's-Gravenhage: Martinus Nijhoff, 1906.

[13] Wignjawirjanta, Pedalangan Djangkep Sedalu-Muput Kartapijoga Tjidra. Solo: Keluraga Sorbarno, 1963.

[14] J. Cramer, "Using pronouns to construct a European identity : The case of politicians at Davos 2008 *," no. Jansen 1999, pp. 94-109, 2009.

[15] C. Thumiger, "PERSONAL PRONOUNS AS IDENTITY TERMS IN ANCIENT GREEK : THE SURVIVING TRAGEDIES AND EURIPIDES 'BACCHAE Author ( s ): Chiara Thumiger The study," Harv. Stud. Classic. Philol., vol. 104, no. May, pp. 139-169, 2008. 